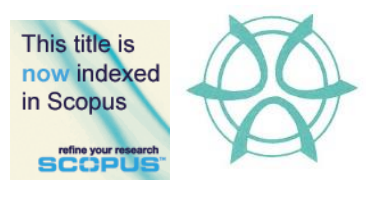

PLANNING MALAYSIA:

Journal of the Malaysian Institute of Planners

VOLUME 17 ISSUE 1 (2019), Page 176 - 185

\title{
ZAKAT HOUSES DESIGN AND PLANNING (QUALITY AND STANDARD) FROM SHARIAH PERSPECTIVE
}

\author{
Srazali Aripin ${ }^{1}$, Khairuddin Abdul Rashid ${ }^{2}$, Azila Ahmad Sarkawi ${ }^{3}$, \\ Sharina Farihah Hasan ${ }^{4}$ \& Puteri Nur Farah Naadia Mohd Fauzi ${ }^{5}$ \\ 1,2,3,4,5 Kulliyyah of Architecture \& Environmental Design \\ INTERNATIONAL ISLAMIC UNIVERSITY MALAYSIA
}

\begin{abstract}
The paper focusses on the provision of shelter or housing for asnaf fakr and miskin by zakat administrators in Malaysia. The objectives of the study are to ascertain whether the design and planning (quality \& standard) of zakat housing (1) satisfies the need and well-being of the households (i.e. the asnafs) in terms of appropriateness and adequacy, (2) meets the requirement of shariah (aesthetic, privacy, space requirements, facilities and amenities) and (3) could potential arrive at the key success factors for zakat houses from shariah perspectives. The study was carried out through desktop analysis of the literature review of zakat, housing for asnafs and house design for shariah added with semi-structured interview of the occupants living in zakat houses. Key findings from the study are the zakat houses occupied by the asnafs are neither appropriate nor adequate in terms of meeting the needs and requirements of the households of the asnafs. Limited literature is found describing the specifications of zakat houses or the state and conditions of such houses and houses repaired or rented. The study recommends that zakat administrator should consider establishing their own and shariah compliant standards for zakat funded housing for the asnafs.
\end{abstract}

Keyword: zakat, design, housing, shariah, standard, asnaf 
PLANNING MALAYSIA

Journal of the Malaysia Institute of Planners (2019)

\section{INTRODUCTION}

One of the most critical problems currently facing Muslims in Malaysia is believed to be the lack of access to decent and affordable housing for the low and middle income families. The problem, relatively widespread, appears to be more acute among families residing in the cities and big towns due to higher costs of living, in contrast to those residing in the rural areas. Consequently, many of the low and middle income families have to endure staying in cramped and often unfavourable living conditions. In Islam, zakat and waqaf are two key instruments that focus on providing assistance to the needy. Although approaches of these two instruments are different, they have common aim to provide assistance to the needy Muslims. Zakat has specific approach as prescribed in $\mathrm{Al}$ Quran and Al-Hadiths whereas waqaf has no direct Quranic injunction except the various verses and hadiths that promote the practice of infaq. Infaq in Arabic term is spending. Conceptually in the Islamic system, it means giving away for the betterment of the society and its members, including the giver and her/his family.

Available literature thus far suggested that lots have been done in terms of assisting the needy and eligible Muslim families including in the provision of housing via zakat and waqaf respectively (Khairuddin, Sharina Farihah, Azila, Jamilah, \& Srazali, 2015). The various Majlis Agama Islam Negeri (MAIN) have been very active in discharging their roles and performing their functions. In effort to boost services and expertise, the government had, in 2004, established the Jabatan Waqaf, Zakat dan Haji (JAWHAR) or the Department of Waqaf, Zakat and Hajj. JAWHAR is provided with administrators and funding to assist MAIN in coming up with methods to improve the administration of the states' zakat and waqaf.

Focussing on housing for the needy Muslims, zakat administrators in Malaysia do provide housing assistances in their disbursement schemes. The Manual of Zakat Disbursement produced by JAWHAR at the Federal level explicitly stated this kind of assistance under the thirty-two (32) schemes of zakat disbursement. It was acknowledged that foods, clothes, housing, education, transportation, medical are the basic needs of people that require assistance for needy person. However, the practice of housing assistance among MAIN varies. In general, the assistance ranges from (i) New house, (ii) Repair, (iii) Monthly rental, (iv) Deposit for low cost house and (v) Cluster house. According to JAWHAR document, asnaf faqr, miskin and muallaf are eligible for this kind of assistance subject to further investigation from the application form filled up by them. This should be the focus of the study by examining the state of housing for the asnafs provided by zakat administrators.

The observation on asnaf cluster house (perumahan berkelompok) provided by MAIN appears to be showing that their houses need improvement in term of their design, size, surrounding and location. In Federal Territory Kuala Lumpur, majority of the houses for asnaf are located in Projek Perumahan Rakyat 
Aripin, S., Rashid, K. A., Sarkawi A. A., Hasan, S.F, Fauzi, \& P.N.F N. M.

Zakat Houses Design and Planning (Quality and Standard) from Shariah Perspective

(PPR) and Projek Perumahan Awam (PPA) under Kuala Lumpur City Hall $(\mathrm{KLCH})$. Thus, the objectives of the study are to ascertain whether the design and planning (quality \& standard) of zakat housing (1) satisfies the need and wellbeing of the households (i.e. the asnafs) in terms of appropriateness and adequacy, (2) meets the requirement of shariah (aesthetic, privacy, space requirements, facilities and amenities) and (3) could potential arrive at the key success factors for zakat houses from shariah perspectives.

Thus, this paper highlights the ideas of a house in Islam, planning requirement and basic house design according to the laws. In this regard, the Federal Territory (Planning) Act 1982 (Act 267), the Uniform Building-by Laws 1984 and Street, Drainage and Building Act 1984 and relevant guidelines on public facilities (GP004-A, JPBD, 2013) are referred. Since there is no published literature to describe the specifications of the asnaf houses or the state and conditions of such houses and preliminary findings indicate that PPR houses are occupied by asnaf, a field survey of PPR houses has been conducted and presented here as benchmarking to the asnaf house that should be provided as shariah compliant standards for zakat funded housing for the asnafs.

\section{HOUSE FROM SHARIAH PERSPECTIVE}

House (shelter) is commonly known as basic necessity to human being. Indeed the maqasid shariah (the ultimate aim of Islamic laws), through its five essentials of preservation namely faith, self, intellect, lineage and property, promotes the idea of shelter provision. In this regard, the Arabic term 'maskan', which also means the house, is derived from an Arabic verb 'sakana', which means to calm down, to repose, to rest, to become quiet and tranquil, and to feel at ease with. Hence, the words 'sukun' and 'sakinah' mean calmness, tranquility, peacefulness, serenity, peace of mind, etc. The house is called 'maskan' in Arabic because it offers its inhabitants a chance to take a break from the demands and pressure of the outside world and concentrate on physical, mental and even spiritual recuperation. Normally, in this tranquil situation of housing arrangement, human well-being and spirit is built up reflecting preservation of faith, self, intellect, lineage and property. This is clearly stated in Al-Qur'an;

And Allah has made for you from your homes a place of rest and made for you from the hides of the animals tents which you find light on your day of travel and your day of encampment; and from their wool, fur and hair is furnishing and enjoyment for a time"

(An-Nahl 16: 80)

In terms of Islamic jurisprudence (fiqh), the organization of family institution, succumbed by housing provision, is mostly governed by fiqh almunakahat. This fiqh outlined Islamic principles related to family life such as sacredness of family life, limiting the relationship of sexes outside of the family 
PLANNING MALAYSIA

Journal of the Malaysia Institute of Planners (2019)

circle, protecting, raising and educating children, public health, enjoyment of life and others. In this regard, Ahmad Farid Moustapha (1986) translated them into physical form in the kind of privacy, building heights, building forms, external spaces, architecture and social interactions. These physical environments are the concern of the general Islamic shariah principles for what house design should be. Meanwhile figh al-mu'amalat governs community life in human dealings and commercial transaction in Islam. The physical manifestation can be implemented in neighbourhood, town, city and bigger scale of planning entity. In this regard, the Companion Sa'ad ibn Abi Waqqas had narrated that the Messenger of Allah once said that: "Four things contribute to happiness are righteous wife, spacious home, righteous neighbour and comfortable means of transport". The lessons from this hadith among others are the importance of family institution signified in righteous wife, house design and neighbourhood planning, embodied in spacious home and righteous neighbour respectively, and good transportation mode and traffic circulation in spatial planning. House, as a semi-private social place, is understood from the Quranic verse;

My Lord, forgive me and my parents and whoever enters my house a believer and the believing men and believing women. And do not increase the wrongdoers except in destruction. (Nuh 71:28)

The verse implies a concept of visiting our friends for good purposes of $u k h u w w a h$ (social bondage) as well as inviting people to our house. Thus, it gives rise to the importance of appropriate house design and its surrounding. Fulfilling the objectives of house provision in Islam is an ibadah. More importantly, the house as a place for worshipping Allah, as Allah's saying in the Quran (interpretation of the meaning):

And We inspired Moosa and his brother (saying): 'Take dwellings for your people in Egypt, and make your dwellings as places for your worship, and perform al-salaah, and give glad tidings to the believers'. (Yoonus:87).

In a hadith, the Messenger of Allah said: "Do not turn your houses into graves ..." (Reported by Muslim, 1/539). In another hadith where the Prophet said: "The likeness of a house in which Allah is remembered and the house in which Allah is not remembered is that of the living and the dead, respectively."

Many Islamic scholars have laid down few basic criteria regarding houses in Islam. The criterions are based on the concept of Islamic urbanization, where the residential quarter is part of the focus in contemporary urbanism. The emphasis of these criterions is on the relationship between Man-and-The Creator and Man-and-Man and can be divided into seven parts: 
Aripin, S., Rashid, K. A., Sarkawi A. A., Hasan, S.F, Fauzi, \& P.N.F N. M.

Zakat Houses Design and Planning (Quality and Standard) from Shariah Perspective

a) Privacy - a house must be capable of protecting a family. The importance of observation on the relationship between non-mahram;

Islam gives great importance to the fundamental human right to privacy.

And do not spy or backbite each other (Al-Hujurat 49:12)

O you who have believed, do not enter houses other than your own

houses until you ascertain welcome and greet their inhabitants

(An-Nur 24:27)

b) Cleanliness - waste disposal, drainage system and separation between bathroom from the toilet;

c) Right of neighbours - prevent light or air from entering the openings of the neighbours' house;

d) Specific area for guests - giving respect to the guest;

e) Prohibits from constructing a house which features of extravagance emphasizing wealth, pride opulence or arrogance - scale and context;

f) Facing the Qiblah - except toilet bowl; and

g) House should be constructed to the values of Islamic arts.

These criteria were used as guideline in formulating the questionnaire for the semi-structured interview with the targeted respondents (asnafs).

\section{PROJEK PERUMAHAN RAKYAT}

Majority of asnafs (the recipients of zakat fund assistance) have been reported by MAIWP (2015) reside in the Projek Perumahan Rakyat (PPR) housing. PPR housing is the government's initiative, under the Ministry of Urban Well-being, Housing and Local Government (MUWHLG), to relocate squatters and meet the needs of low-income group for housing. Eligibility criteria is set for family with total household monthly income of less than RM2,500.00. The eligible residents under this program can either rent or own the unit.

The type of housing provided under PPR are 18-storey flats (high rise), 5 -storey walk-up flats in the major cities and terrace houses in coastal and suburban areas. Based on the published materials, houses under PPR adopt the same specifications of design and planning of Low-Cost Housing set out by the National Housing Standard for Low-Cost Housing flats with floor area of not less than $700 \mathrm{sq}$ ft. The PPR house features 3 bedrooms, 1 living room, 1 kitchen and 2 bathrooms with the provision of basic community facilities of community hall, musolla, food stalls, kindergarten, facilities for people-with-disability, children playground with greenery area and garbage house (National Housing Department, 2015). 
PLANNING MALAYSIA

Journal of the Malaysia Institute of Planners (2019)

\section{METHODOLOGY}

The study commenced with the review of house design from shariah perspective, and the background understanding of the development of PPR housing in Malaysia. The criteria of houses from shariah perspective were identified from literature review and used as the basis to examine the existing design specifications of PPR housing occupied by the asnafs. A semi-structured questionnaire survey was also developed to gauge the satisfaction level of the occupants. A Likert scale of 1 (least satisfied) to 5 (highly satisfied) was used as measurement to gauge the satisfaction level of the respondents (i.e. asnafs). A typical PPR house design was selected and measured during the field survey for quantitative analysis. Findings were derived based on the qualitative and quantitative analysis from the data gathered (observations, interviews and measurements). The methodology adopted would lead to the key findings in the provision of house design and planning (quality and standards) of zakat houses its appropriateness and adequacy from the shariah perspective.

\section{FIELDWORK}

The survey was carried out through face-to-face interviews with 47 household heads residing at PPR (80.9\%) and PPA (19.1\%) within Kuala Lumpur. Majority of the respondents $(74.5 \%)$ have been living in PPR for more than 6 years, with $21.3 \%$ between 6 and 10 years and 53.2\% more than 11 years. The residents are the asnafs, therefore deemed appropriate as respondents for the study. Questions were formulated to investigate on the basis of two main components: (1) the house condition and (2) the provision of basic facilities as summarised in Table 1.

Table 1: Two components of questions formulated in the questionnaire

\begin{tabular}{|c|c|c|c|}
\hline \multicolumn{2}{|c|}{ Component 1} & \multicolumn{2}{|c|}{ Component 2} \\
\hline House condition & $\begin{array}{l}\text { Investigation } \\
\text { aspects }\end{array}$ & $\begin{array}{l}\text { Provision of basic } \\
\text { facilities }\end{array}$ & $\begin{array}{l}\text { Investigation } \\
\text { aspects }\end{array}$ \\
\hline House space & $\begin{array}{l}\text { Living, dining, no. } \\
\text { of bedrooms, } \\
\text { kitchen, study area, } \\
\text { toilet. }\end{array}$ & $\begin{array}{l}\text { Parking, footway, } \\
\text { green field, } \\
\text { children } \\
\text { playground }\end{array}$ & $\begin{array}{l}\text { Availability, } \\
\text { distance, } \\
\text { accessibility and } \\
\text { condition. }\end{array}$ \\
\hline $\begin{array}{c}\text { House } \\
\text { infrastructure }\end{array}$ & $\begin{array}{l}\text { Availability of } \\
\text { electricity, water, } \\
\text { telephone, internet, } \\
\text { and satellite TV. }\end{array}$ & $\begin{array}{l}\text { facilities, musolla, } \\
\text { garbage house, } \\
\text { shops, community } \\
\text { hall, bus stop, }\end{array}$ & \\
\hline Home furniture & $\begin{array}{l}\text { Sofa, dining table, } \\
\text { fridge, TV, bed, } \\
\text { computer. }\end{array}$ & $\begin{array}{l}\text { security public } \\
\text { telephone, clinic }\end{array}$ & \\
\hline
\end{tabular}


Aripin, S., Rashid, K. A., Sarkawi A. A., Hasan, S.F, Fauzi, \& P.N.F N. M.

Zakat Houses Design and Planning (Quality and Standard) from Shariah Perspective

A typical floor plan (18-storey flat) of PPR house layout design and planning was drawn as shown in Figure 1, and floor area was measured.

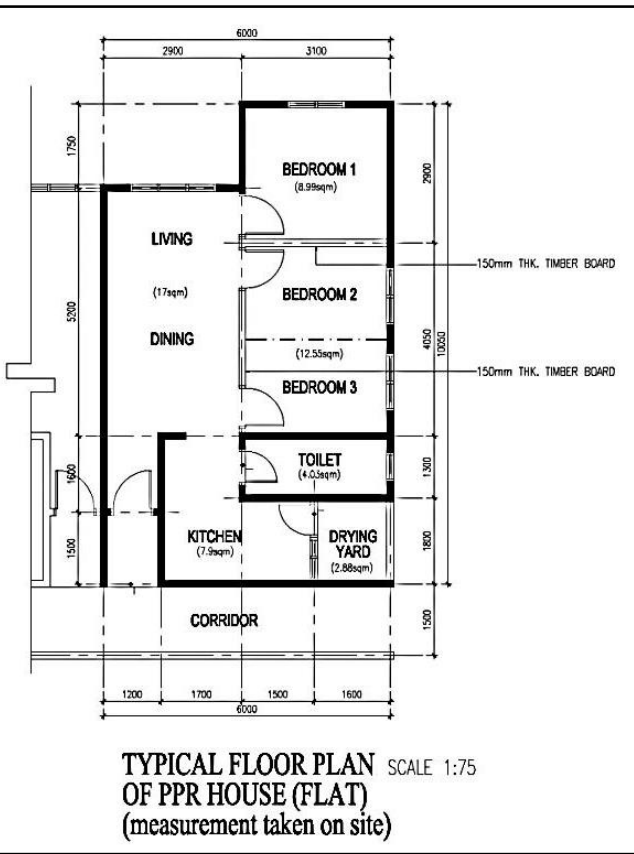

\begin{tabular}{|c|c|c|}
\hline \multicolumn{3}{|c|}{ Total Built-up Area (Sqm) } \\
\hline Living \& Dining & $=$ & 17.00 \\
\hline Bedroom 1 & $=$ & 8.99 \\
\hline Bedroom 2 \& 3 & $=$ & 12.55 \\
\hline Toilet & $=$ & 4.03 \\
\hline Kitchen & $=$ & 7.90 \\
\hline Drying yard & $=$ & 2.88 \\
\hline Total & $=$ & 53.35 (574 sq. ft.) \\
\hline
\end{tabular}

Figure 1: A typical floor plan and floor area of PPR House occupied by asnafs (18-storey flat)

\section{RESULTS AND FINDINGS}

\section{House Condition}

There were two types of PPR housing included in the survey, with $78.8 \%$ of the respondents residing in the 18 -storey house flat and the other $21.2 \%$ residing in the 5-storey walk-up flat. The measured built-up area (see Figure 1) for a typical 18 storey flat house of PPR was found to be $53.4 \mathrm{sqm}$ (574sqft.), a shortfall of 
PLANNING MALAYSIA

Journal of the Malaysia Institute of Planners (2019)

126sqft from 700sqft of what is required as specified by the National Housing Department (2015).

It has been found that the number of bedrooms provided is only two bedrooms (i.e. bedrooms $2 \& 3$ were considered one) with 3 doors. The third bedroom was found to be created by the residents and was erected using a partition wall dividing the space (shown as dotted line in Figure 1). This is to fulfil the need of a family for additional room.

Through fieldwork, it has been found that the number of toilets provided is only one, not two as specified by the National Housing Standards for Low-Cost Housing. This is corroborated with the survey result indicating that $95.7 \%$ of the respondents confirmed that there is no provision of the third bedroom.

The material used for the bedrooms' wall is timber board. This would not provide good acoustic and privacy comfort level between the most private area of the house (bedrooms) and the social interaction space (living). At the same time, the space for visitors and relatives to perform prayers, particular for female is limited. The respondents also claimed that with the limited space and the existing furniture, the house is not suitable for social interaction as well as gender segregation not complying to shariah.

In terms of dilapidation, $53.2 \%$ of the respondents indicate that the house condition is deteriorating with $8.5 \%$ respondents claim that dilapidated timber window sill and leaking at the concrete floor slab above require repair works. However, $46.8 \%$ of the respondents indicate that the house is in perfect condition.

Majority of the respondents felt blessed to be eligible for PPR housing scheme and to have a place for shelter. However, Table 2 shows that respondents who are not satisfied in terms of the house comfort was slightly higher $(24.4 \%)$ than those who are satisfied (20\%).

Table 2: Result of Satisfaction level on house comfort

\begin{tabular}{lccccc}
\hline & $\begin{array}{c}\text { Least } \\
\text { Satisfied }\end{array}$ & $\begin{array}{c}\text { Not } \\
\text { Satisfied }\end{array}$ & Neutral & Satisfied & $\begin{array}{c}\text { Highly } \\
\text { Satisfied }\end{array}$ \\
\cline { 2 - 6 } & 1 & 2 & 3 & 4 & 5 \\
\hline $\begin{array}{l}\text { Overall satisfaction } \\
\text { on house comfort }\end{array}$ & $2.2 \%$ & $22.2 \%$ & $55.6 \%$ & $20.0 \%$ & $0 \%$ \\
\hline
\end{tabular}

\section{Provision of Basic Facilities}

The basic facilities provided for the community in PPR housing scheme are: parking space for cars, motorcycles and people-with-disability (PWD), green open space and children playing equipment, musolla, nearby schools, mini-shops, public telephone, community hall, garbage house, bus stop and Clinic 1 Malaysia.The provision of Musolla in terms of space, location and accessibility received the highest percentage of agreement $(97.9 \%)$ from the respondents. Meanwhile, the highest disagreement $(95.7 \%$, i.e. 'No') was on parking 
Aripin, S., Rashid, K. A., Sarkawi A. A., Hasan, S.F, Fauzi, \& P.N.F N. M.

Zakat Houses Design and Planning (Quality and Standard) from Shariah Perspective

sufficiency. The residents also expressed their dissatisfaction that the community hall cannot be used due to the hall poor condition.

\section{DISCUSSIONS}

The preliminary finding confirms that there is no design specifications of house for the asnafs. The Zakat authorities through MAIN do provide monetary assistance for housing to the asnafs. However, this study shows that the house design and its surrounding environment with community facilities are provided based on the Low-Cost Housing scheme specified by the National Housing Department (2015), and not from the Zakat authorities. Thus, their role stops at providing monetary assistance.

The findings of the field survey prove that the living condition and its surrounding environments of the asnafs is cramped and poor compared to a modern living environment. Evidences clearly show that while the asnafs are very grateful to have shelter in PPR, the house design and planning (quality and standards) meeting shariah compliance have to be compromised. Visual and acoustic privacies and gender segregations during social interaction are not achieved with the existing house design experienced.

The minimum number of three (3) bedrooms is not provided and if the additional bedroom is created through partition, the size and space would not comply with the requirement of Building By-Law. The research takes note that the new policy of the new development of PPR housing has set that the minimum number of bedrooms must be three (3).

Complaints made by the respondents on the social decay (drug addicts, poor hygiene among the residents, irresponsible residents etc.) were recorded and evident in PPR housing scheme where the asnafs reside.

\section{CONCLUSION AND RECOMMENDATIONS}

This paper reports on a study on the provision of zakat houses for asnaf from the shariah perspectives. On the basis of the study's objectives, the following are the key findings:

a. The present design and planning (quality \& standard) of zakat housing provided for asnaf do not meet their needs and requirements in terms of appropriateness and adequacy (space, privacy, aesthetic, requirements, facilities and amenities).

b. The study also confirmed that there is no literature to suggest the established specification of zakat houses specifically for the asnaf. In this absence, the asnaf reside in PPR housing based on the specification of Low-Cost Housing in Malaysia. As a result, many of the asnafs' families have to endure staying in cramped and often unfavourable living condition.

c. The key factors influencing the satisfaction of the asnaf in the design and planning (quality and standard) of PPR houses are size, space, materials 
PLANNING MALAYSIA

Journal of the Malaysia Institute of Planners (2019)

used, privacy, and safety and security as well as hospitality. As such, these factors could be used as the indicators for Shari'ah Compliance for zakat houses. Hence, it could be concluded that the key success factors in the design and planning (Quality and Standard) for zakat houses from the shariah perspectives is to consider these indicators.

\section{ACKNOWLEDGEMENT}

The study reported in this paper is funded by the Transdisciplinary Research Grant Scheme (Project ID: TRGS16-01-004-0004), Ministry of Higher Education Malaysia.

\section{REFERENCES}

Ahmed Farid Moustapha (1986, August). Islamic values in contemporary urbanism. Forst Australian International Islamic Conference. August 1986, Melbourne: Australia.

Khairuddin, A._R., Sharina Farihah, H., Azila, A. S., Jamilah, O., \& Srazali, A. (2015). Preliminary discussion on the potential of zakat-waqf collaboration in the provision of housing for the needy Muslims. National Conference on Zakat and Economic Development. June 1, 2015, Kuantan, Pahang.

MAIWP (2015). Laporan Tahunan MAIWP 2013. Retrieved from http://www.maiwp.gov.my/i/index.php/perkhidmatan-kami/muatturun/category/23-laporan-tahunan. Accessed on $27^{\text {th }}$ August 2015.

National Housing Department (2015). Information on People's Housing Programme $(P H P)$ or Program Perumahan Rakyat (PPR). Retrieved from: http://ehome.kpkt.gov.my/index.php/pages/view/133 